Jurnal Kesehatan Perintis (Perintis's Health Journal) 8 (1) 2021: 75-81

Contents list available at JKP website

PERINTIS Jurnal Kesehatan Perintis (Perintis's Health Journal)

Journal homepage: https://jurnal.stikesperintis.ac.id/index.php/JKP

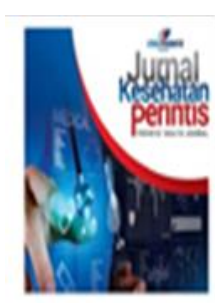

Literature Review

\title{
Aesthetic Expression dalam Praktik Keperawatan
}

\author{
Junaidy Suparman Rustam \\ Sekolah Tinggi Ilmu Kesehatan Yarsi Sumatera Barat, Indonesia
}

Article Information :

Submission: May 05, 2021; Revised:Jun 26, 2021; Accepted:Jun 30, 2021; Available online: Jun 30,2021

*Corresponding author : junaidy.rustam25@gmail.com

\begin{abstract}
ABSTRAK
Aesthetic expression adalah hubungan yang unik antara pasien dan perawat dengan melakukan tindakan kepedulian yang berdasarkan pada pengalaman hidup, keyakinan individu, pengembangan diri, dan memungkinkan perawat dapat melihat dan mengintegrasikan diri mereka ke semua tindakan asuhan keperawatan. Studi ini merupakan tradisional literatur review yang bertujuan untuk mengeksplore penerapan aesthetic expression dalam praktek keperawatan. Kriteria inklusi pada studi literatur ini antara lain; jurnal yang membahas tentang bentuk penerapan aesthetic expression dalam praktek keperawatan, artikel bebahasa Inggris dan Indonesia, artikel terbitan tahun 2009-2020. Strategi penelusuran literatur review ini dilakukan dengan mengakses beberapa data base seperti Proquest, CINAHL, Elsevier/Science Direct, Pubmed, dan Google Schoolar dengan menggunakan kata kunci aesthetic, aesthetic expression, nursing care, nursing practice, estetika dan praktik keperawatan, Hasil dari literatur review menemukan beberapa bentuk penerapan asthetic expression dalam praktek keperawatan meliputi terapi music,terapi dance, puisi, humor, dan visual. Studi selanjutnya diharapkan dapat mengembangkan penelitian tentang penerapan aesthetic expression khususnya pada spesifikasi bidang dalam praktek keperawatan.
\end{abstract}

Kata Kunci: estetika, aesthetic expression, praktik keperawatan, asuhan keperawatan

\section{ABSTRACT}

Aesthetic in nursing were important in order to experience a positive mood and

sense of personal strength for the patients. The implementation of aesthetic expression in nursing practice can be a great challenge in alleviating the stress that a patient in the hospital may experience. Aesthetic as one kind of therapeutic use in nursing practice can be provided by interpersonal communication through the arts to hear and to meet patients in real demands. Therefore, nurses need to create the context of aesthetic expression in which they practice through their action or non-action. This study was purposed to review the literature concerning in the implementation of aesthetic expression in nursing practice. Methods: Traditional literature review was conducted by analyzing published literature in the years 2009 to 2020. The data were searched through Scopus, ProQuest, Elsevier/Science Direct, CINAHL, PubMed and Google Scholar based on PICO question with keywords; aesthetic, aesthetic expression, nursing practice, nursing care. The importance of supportive aesthetic expression is obvious, and there are no arguments for not using these in nursing practice. Moreover, it can be pointed out that neither the patient nor the nurse requires to use of cognitive distraction with aesthetic means of expression may make it easy to integrate in nursing practice. Kinds of aesthetic 
expression in nursing practice were music therapy; poetry; humor; dance; and visual art. The knowledge from this study can be useful for nurses and other healthcare providers to develop quality care for patients by integrate aesthetic expression in nursing practice.

\section{Keywords: aesthetic, aesthetic expression, nursing practice, nursing care}

\section{PENDAHULUAN}

Aesthetic expression dalam praktek keperawatan merupakan hubungan yang unik antara pasien dan perawat yang berupa hubungan antar individu atau seluruh komunitas (Chen, Tsai, and Chen 2011). Seorang pasien tidak hanya mengalami masalah fisik seperti nyeri, sesak nafas, penurunan berat badan, gangguan mobilitas tetapi pasien juga mengalami gangguan psikososial dan spiritual yang dapat mempengaruhi kualitas hidup pasien tersebut (Tierney, 2003).

Salah satu teori keperawatan yang dikembangkan oleh Martha E. Rogers tentang "Unitary Human Beings" menyatakan bahwa manusia merupakan individu yang holistik, memiliki hubungan timbal balik antara individu dengan lingkungan disekitarnya. Rogers, memandang keempat konsep dalam paradigma keperawatan yang terdiri dari manusia, lingkungan, kesehatan, dan keperawatan merupakan satu kesatuan yang utuh dan saling mempengaruhi antaraasatu dengan yang lainnya. Menurut Roger, pengetahuan perawat tentang penerapan aesthetic expression dalam praktik keperawatan merupakan pengetahuan yang bersifat subjektif tentang bagaimana perawat mencari pengalaman dan arti hidup dalam merawat pasien. Pengetahuan perawat mengenai aesthetic expression juga dapat diartikan sebagai bentuk kemampuan dalam mengeksplor pengalaman dan arti hidup bagi pasien, dimana pengetahuan ini berfokus pada intuisi, interpretasi, pemahaman, penghargaan, imanjinasi dan sensitivitas yang dimiliki perawat (Dossey, 2008).

Tindakan seperti menyapa pasien, merupakan salah satu bentuk aesthetic expression dimana adanya ekspresi antara dua orang yang bertemu satu sama lain (Pagina, 2013). Bentuk hubungan antara pasien dan perawat menggambarkan adanya kepedulian yang didasari pada pengalaman hidup, keyakinan individu, pengembangan diri, dan memungkinkan perawat dapat melihat dan mengintegrasikan diri mereka ke semua tindakan asuhan keperawatan (Cody, 2002). Aesthetic expression dapat dijadikan sebagai salah satu jenis tindakan non farmakolologis dalam keperawatan dengan melakukan komunikasi interpersonal melalui seni untuk mendengar dan untuk memenuhi kebutuhan pasien (Chen, 2012). Oleh karena itu hubungan antara keperawatan dan estetika memeiliki hubungan yang kuat terhadap nilai profesional keperawatan dan keunggulannya (Katimis, 1993).

Penerapan aesthetic expression dalam keperawatan dapat membuat pasien merasa lebih nyaman, berpikiran positif pada saat dirawat di rumah sakit (Wikstrom, 2002). Berapa tindakan non farmakologis dapat dijadikan sebagai bentuk penerapan aesthetic expression dalam praktek keperawatan seperti penerapan visual art, terapi musik, atau terapi murottal (Ariff et al., 2013; Awa,2014 ; Rustam, 2017), terapi humor, dance, dan puisi. Studi literatur ini bertujuan untuk mengeksplore tentang aesthetic expression dan penerapannya dalam praktek keperawatan.

\section{METODE}

Studi Literatur (literature review) dilakukan dengan mengumpulkan sejumlah buku dan artikel ilmiah yang berkaitan dengan tentang penerapan aesthetic expression dalam praktek keperawatan yang dipublikasikan pada tahun 2000-2020, dengan menggunakan kata kunci berdasarkan fomat PICO. Strategi pencarian literatur dilakukan melalui akses ke databased online seperti Proquest, CINAHL, Elsevier/Science Direct, Pubmed, dan Google Schoolar. Artikel yang digunakan diterbitkan dalam bahasa Inggris dan bahasa Indonesia. Kata kunci yang digunakan untuk pencarian meliputi aesthetic, aesthetic expression, nursing care, nursing practice, estetika dan praktik keperawatan. Semua kata kunci ini dicampur dalam kombinasi yang berbeda.

\section{HASIL \& PEMBAHASAN \\ Konsep Aesthetic dalam Keperawatan}

Menurut teori Carper (2010) dijelaskan bahwa estetika dalam keperawatan merupakan apresiasi empati terhadap 
pengalaman pasien, dan pelakasanaan asuhan keperawatan yang menjadi satu kesatuan yang bermakna sebagai bentuk asuhan yang bersifat holistik dan kreatif. Estetika dalam praktik keperawatan dapat diartikan sebagai keterlibatan pasien dalam perawatan secara harmonis. Harmoni ini dapat menghasilkan lingkungan kreatif yang berkaitan dengan keinginan, makna, dan keindahan dalam praktik keperawatan (Kim, 1993 dikutip dalam Rustam, 2017). Selain itu, estetika dalam asuhan keperawatan merupakan suatu kombinasi fakta ilmiah dengan imajinasi kreatif dan sekaligus menggabungkan semua pengetahuan keperawatan (Redmehr, Ashktorab, \& Abedsaeedi, 2015).

Estetika dalam keperawatan sangat penting agar pasien mengalami suasana hati yang positif dan rasa kekuatan pribadi. Perawat dituntut untuk mampu menjaga nilai estetika dalam praktik keperawatan untuk mengurangi stres yang mungkin dialami pasien selama berada di rumah sakit (Wikström, 2002). Praktik keperawatan dapat dilakukan berdasarkan sifat perawat dan cara tindakan tersebut dilakukan. Perawat menciptakan konteks di mana mereka berlatih melalui tindakan atau non-tindakan. Oleh karena itu, hubungan filosofis antara praktik keperawatan dan estetika berakar pada nilai profesional asuhan dan kesempurnaan (Katimis, 1993). Namun, persepsi dan penilaian estetika dalam keperawatan tidak hanya sekedar proses kognitif, tetapi juga melibatkan perasaan (Schindler, et al., 2017).Estetika sebagai salah satu jenis penggunaan terapeutik dalam asuhan keperawatan dapat diberikan melalui komunikasi interpersonal melalui seni mendengar dan memenuhi tuntutan pasien secara nyata (Chang \& Chen, 2012).

Estetika dalam keperawatan dapat diartikan sebagai suatu hubungan unik antara perawat dan pasien, yang bisa bersifat individu atau kelompok (Chin \& Kramer, 1999). Sebagai contoh tindakan menyapa pasien dengan maksud membangun koneksi merupakan sebuah nilai estetika di mana dua orang saling bertemu. (Pagina, 2013). Hubungan interpersonal yang dibentuk oleh tindakan keperawatan didasarkan pada pengalaman hidup, keyakinan individu, dan eksplorasi diri. Sumber daya internal memungkinkan perawat untuk melihat dan mengintegrasikan diri ke dalam tindakan perawatan secara menyeluruh (Mitchell \& Cody, 2002).

\section{Penerapan aesthetic expression dalam praktek keperawatan}

Aesthetic expression adalah bagian penting dari keperawatan. Banyak penelitian menjelaskan bagaimana menggunakan berbagai jenis estetika dalam praktik keperawatan. Pentingnya Aesthetic expression sangat jelas, dan penting untuk diterapkan dalam praktik keperawatan (Wikström, 2002). Aesthetic expression yang diberikan perawat tidak memerlukan adanya pelatihan khusus sehingga sangat mudah untk diterapkan dalam praktik keperawatan (Wikström, 2002). Aesthetic expression juga berkaitan dengan nilai budaya yang dianut oleh seorag perawat (Víctor, 2013). Wikström (2002) menjelaskan alasan perawat menggunakan Aesthetic expression dalam praktik keperawatan adalah untuk menunjukkan kombinasi antara fakta ilmiah dan imajinasi kreatif yang ditunjukkan dalam praktik keperawatan.

Keperawatan, sebagai estetika adalah pemahaman perawat tentang perawatan individual dan kemampuan mereka untuk memberikan asuhan perawatan dalam keadaan khusus (Smith, 2015). Aesthetic expression dalam keperawatan sangat penting agar pasien dapat mengalami suasana hati yang positif dan rasa kekuatan pribadi, merupakan tantangan besar untuk mempertahankan standar estetika yang tinggi sementara pada saat yang sama tidak menambah tetapi mengurangi tekanan yang mungkin dialami seseorang di rumah sakit (Wikstrom, 2002). Robinson (2014) menggambarkan aesthetic expression sebagai cara untuk menunjukkan eksistensi perawat kepada pasien dengan menggunakan intuisi untuk mengerti kebutuhan mereka. Menurut Wikstrom (2002) manfaat aesthetic expression adalah untuk membantu pasien dalam menghabiskan waktu, mengalihkan perhatian pasien dari rasa sakit, suatua cara untuk membuat pasien dapat beristirahat dengan tenang, cara untuk mengenal pasien 
lebih dekat, merangsang komunikasi yang efektif dengan pasien, dan mendorong interaksi dengan pasien.

\section{Bentuk penerapan aesthetic expression dalam praktek keperawatan}

\section{Musik}

Berdasarkan lima literatur yang didapatkan menunjukkan bahwa music memliki manfaat yang positif bagi pasien pada berbagai populasi. Penggunaan musik dalam asuhan keperawatan memiliki efek positif seperti menurunkan intensitas nyeri (Lidsay, 1997), meningkatkan mood, menurunkan kecemasan, dan memeberikan efek relaksasi (McCarty et al., 1998). Pemenuhan kebutuhan pasien akan nilai estetika dapat dilakukan secara pasif, seperti perawat dapat menawarkan pasien untuk mendengarkan musik dari radio yang terhubung ke tempat tidur pasien atau memberikan pilihan jenis music yang disukai.

Terapi musik merupakan terapi yang dilakukan menggunakan musik dan aktivitas musik untuk memfasilitasi proses terapi dalam membantu kliennya. Sebagaimana halnya terapi yang merupakan upaya yang dirancang untuk membantu orang dalam konteks fisik atau mental, terapi musik mendorong klien untuk berinteraksi, improvisasi, mendengarkan, atau aktif bermain musik (Djohan, 2006; dalam Geraldina, 2017). Musik bisa menyentuh individu baik secara fisik , psikososial, emosional, dan spiritual (Chiang, 2012 di dalam Novita, 2012). Mekanisme musik adalah dengan menyesuaikan pola getar dasar tubuh manusia, vibrasi musik yag terkait erat dengan frekuensi dasar tubuh atau pola getar dasar dapat memiliki efek penyembuhan yang sangat hebat bagi tubuh, pikiran, dan jiwa manusia (Andrzej, 2009 di dalam Novita, 2012).

Menurut Novita(2012) Menyatakan bahwa terpai musik telah terbukti efektifitasnya untuk diimplementasikan pada bidang kesehatan, karena musik bisa menurunkan kecemasan, nyeri, stress, dan menimbulkan mood yang positif. Selain itu musik juga melibatkan lama hari rawat di rumah sakit serta mengurangi biaya rumah sakit. Hasil penelitian terapi musik pada pasien bukan koma juga telah terbukti menunjukkan efek positif terhadap status hemodinamika, gambaran EKG, dan pernapasan. Kemper dan Danhauer (2005) di dalam Novita, 2012 menyatakan bahwa musik dapat mengurangi stres dan nyeri. Musik berpengaruh terhadap mekanisme kerja sistem saraf otonom dan hormonal, sehingga secara tidak langsung dapat berpengaruh terhadap kecemasan dan nyeri. Pasien yang diterapi dengan menggunakan musik akan tampak lebih rileks dan tenang (Wijayanti, 2016).

Bentuk lain dari penerapan aesthetic expression dengan musik, adalah terapi murrotal atau mendengarkan lantunan ayat suci Al-qur'an. Dari tiga literatur menunujukan terapi murrotal memiliki efek positif pada pasien muslim dengan ventilasi mekanik (Ariff et al., 2013; Awa, 2014; Rustam 2017). Saat mendengarkan pembacaan ayat suci Al-quran respons stres dapat dikurangi, kenyamanan dapat ditingkatkan, dan respons relaksasi secara menyeluruh dapat diinduksi (Rustam 2017). Selain itu, intervensi ini dapat mengurangi rangsangan stres dengan menyinkronkan ritme tubuh seperti pernapasan dan detak jantung (Awa, 2014; Rustam 2017). Oleh karena itu, mekanisme pembacaan al-qur'an dapat dianggap sebagai intervensi yang menghibur dan diintegrasikan ke dalam praktik keperawatan untuk meningkatkan kenyamanan secara holistik pada pasien.

Musik terapi alam adalah salah satu terapi komplementer dalam penatalaksaan penderita yang mengalai gangguan tidur. Tindakan terapi musik memiliki pengaruh yang efektif dalam mengurangi gejala depresi pada penderita yang mengalami diagnose medis yang berbeda pada tingkat usia yang berbeda. Tidak adanya batasan bagi pengguna terapi ini, dan dapat diberikan pada semua penderita ganguan tidur (Dona. Mira,2010 di dalam Waruwu, 2019). Musik suara alam adalah jenis musik yang baru akibat dari perkembangan teknologi, bentuk musik klasik dengan suara alam.komposisi suara yang dihasilkan oleh kejadian alam, seperti angin, burung, sungai, hujan dan. Gelombang laut.suara alam juga memiliki frekuensi yang berbeda, (Dhona,2016 di dalam Waruwu, 2019).

\section{Puisi}

Puisi telah digunakan dalam praktik keperawatan untuk meningkatkan pemahaman tentang pentingnya estetika dan humaniora. Puisi sebagai bentuk penerapan 
nilai estetika dapat meningkatkan pemahaman tentang pengalaman hidup pasien dan perawat serta hubungan mereka satu sama lain. Perawat juga dapat menggunakan puisi sebagai terapi modalitas dalam asuhan keperawatan dan cara untuk meningkatkan komunikasi dengan pasien dalam berbagai kondisi (Hunter, et al., 2010). Sebagai contoh, sebuah studi yang dilakukan oleh Pfeifer (1995) menggambarkan pengalamannya tidak dapat berhubungan dengan pasien yang meninggal karena gagal ginjal karena perbedaan ras dan budaya. Pasien menggunakan puisi untuk mengkomunikasikan perasaannya. Setelah membaca puisi, Pfeifer mulai memahami pengalaman pribadinya tentang kematian. Hunter (2010) menyimpulkan bahwa puisi adalah Aesthetic expression dalam praktik keperawatan, menggugah dan dapat dipahami lintas waktu dan budaya. Penggunaan metafora dan bahasa emosi memberikan kesempatan untuk mendapatkan makna dan kebenaran baru tentang pengalaman hidup dan hubungan perawat-pasien. Puisi juga memberikan kesempatan untuk melihat hubungan unik antara penyair, puisi, pembaca, dan dunia melalui interpretasi (Hunter, et al., 2010). Puisi dalam praktik keperawatan dapat dijadikan sebagai aktivitas yang bersifat manusiawi (Edwards, 2015)

\section{Humor}

Humor dalam praktik keperawatan dianggap oleh banyak peneliti sebagai alat penting dan variabel psikologis penting yang memberikan berbagai efek postif terhadap pasien. Humor merupakan aesthetic expression yang dapat meningkatkan kenyamanan fisik dan psikologis (Buxman, 1991 seperti dikutip dalam Wikström, 2002). Humor juga dapat menurunkan ketegangan, kecemasan, stres selama dirawat di rumah sakit (Wikström, 2002). Misalnya, Bullock (1983) menemukan bahwa humor untuk anak-anak terbukti tidak hanya efektif untuk mengurangi ketegangan tetapi juga kecemasan dan stres. Studi serupa yang dilakukan Schindler et al (2017) menemukan bahwa kebahagiaan pasien jelas berbeda setelah mendengarkan humor yang diberikan oleh perawat.

Terapi humor mempunyai pengaruh positif terhadap kesehatan dan penyakit, humor dapat digunakan dalam upaya membina hubungan, humor dapat meredakan ketegangan, menurunkan kecemasan, melepaskan kemarahan, memfasilitasi belajar, atau mengatasi perasaan yang menyakitkan (Kozier, $2011 \mathrm{di}$ dalam Putri, 2014). Penggunaan tawa dalam terapi humor akan menghasilkan perasan lega pada individu. Ini disebabkan tawa secara alami menghasilkan pereda stres dan rasa sakit. Tertawa akan menggerakkan bagian dalam tubuh, mengaktifkan sistem endokrin sehingga mendorong penyembuhan suatu penyakit. Terapi Tawa merupakan metode terapi dengan menggunakan humor dan tawa, yang dikombinasikan dengan yoga dan meditasi, untuk membantu individu mengurangi gangguan fisik maupun gangguan mental

\section{Tarian}

Berdasarkan tiga literatur dapat disimpulkan bahwa terapi menari atau tarian merupakan bentuk refleks gerak seseorang berasal dari pikiran dan perasaan. Perilaku individu yang dikenal dengan baik ini dapat dilihat kerangka teori digunakan untuk mendeskripsikan proses dan hasil akhir terapi tari dan gerak. Menari sebagai bagian dari estetika dapat didorong dan dipupuk dalam memberikan asuhan keperawatan (Wikström, 2002). Tari merupakan satusatunya "karya seni" yang merupakan jalan untuk mengkomunikasikan aesthetic expression (Víctor, 2013). Misalnya, tarian dapat memberikan efek yang postif pada pasien geriatri tetapi tidak untuk pasien dengan perawatan akut (Wikström, 2002).

Terapi tari dan gerak merupakan bentuk refleks gerak seseorang berasal dari pikiran dan perasaan (Supriadin, 2019). Perilaku individu yang dikenal dengan baik ini dapat dilihat kerangka teori digunakan untuk mendeskripsikan proses dan hasil akhir terapi tari dan gerak (Kushariyadi, 2011 di dalam Supriadin, 2019). Bailey (2007) di dalam Hodgin (2009) menetapkan bahwa physical therapy dapat dilakukan dengan aman pada pasien gagal nafas akut yang membutuhkan ventilasi mekanik lebih besar dari 4 hari. Sebuah studi dari Taiwan juga menunjukkan sederhana peningkatan dalam Indeks Barthel Skor Aktivitas Kehidupan Sehari-hari (BI) setelah enam minggu program pelatihan fisik (Chiang, 2006). 


\section{Visual art}

Berdasarkan 3 literatur dapat di simpulkan bahwa terapi visual art merupakan suatu kreasi seni yang dapat mengembangkan kemampuan coping pasien terhadap stres dan masalah kesehatan lainnya. Visual art dapat digunakan untuk menunjukkan aesthetic expression, seperti bunga yang diletakkan di samping tenpat tidur dan mendapatkan cahaya matahari langsung, merupakan suatu pemandangan indah yang dapat dirasakan oleh pasien sebagai bentuk dimensi sensorik dalam praktik keperawatan.

Seni rupa seperti lukisan atau patung dapat digunakan untuk menunjukkan aesthetic expression gan dalam praktik keperawatan (Schindler, et al., 2017). Lingkungan rumah sakit sering didominasi oleh nilai estetika dan kesederhanaan (Heslet \& Dirckinck-Holmfeld, 2007). Selain itu, lingkungan rumah sakit memiliki pengaruh yang kuat terhadap emosi dan kenyamanan pasien. Untuk sembuh dari penyakit, pasien membutuhkan elemen positif dan nilai estetika di lingkungannya, seperti bunga di samping tempat tidur, cahaya alami, pemandangan yang indah (Timmermann, Uhrendeldt, Hoyye, \& Birkelund, 2015). Penerapan nilai estetika di lingkungan rumah sakit dapat menciptakan suasana nyaman dan santai.

Studi sebelumnya oleh Timmermann et al (2012) menemukan bahwa penerapan visual art di lingkungan rumah sakit memberikan dampak emosi positif bagi pasien kanker dalam situasi rentan dengan memberikan dekorasi estetika dan tempat kecil yang nyaman untuk percakapan atau relaksasi yang menciptakan rasa kesederhanaan. Intervensi estetika ini juga memperkuat mood positif dan kekuatan pribadi pasien kanker.

Visual art dalam teori praktik keperawatan estetika, menjelaskan bahwa lingkungan dianggap sebagai lingkungan artistik dimana orang berinteraksi dengan lingkungan. Menggunakan estetika dalam keperawatan dan fokus pada nilai memahami pemandangan indah dari jendela, bunga diatas meja dan karya seni yang dapat dilihat dari tempat tidur rumah sakit dan mendengarkan musik (Kongsuwan, 2018)

Visual art therapy biasanya digunakan sebagai intervensi psikologi seperti untuk mengatasi kecemasan ataupun trauma pada kasus kekerasan (Malchiodi, 2001 di dalam Sholihah, 2017). Seiring dengan perkembangan intervensi psikologis yang mencakup pikiran dan tubuh (mind-body intervention), visual art therapy juga dapat digunakan sebagai intervensi psikologis yang mencakup pikiran dan tubuh. Oleh karena itu beberapa penelitian yang bertujuan untuk membuktikan hubungan antara proses kreasi dan art therapy dan respon fisiologis tubuh dalam bidang kesehatan mulai dikembangkan (Malchiodi, 1993 di dalam Sholihah, 2017). Sholihah (2017) menyimpulkan pendapat dari beberapa ahli yang melakukan penelitian yang menggunakan visual art therapy sebagai intervensi psikologis yang mendukung perlakuan medis. Visual art therapy merupakan suatu aestehetic expression yang dapat mengembangkan kemampuan coping pasien terhadap stres dan gejala-gejala kesehatan

\section{KESIMPULAN}

Berdasarakan studi literatur ini dapat disimpulkan bahwa estetika merupakan suatu nilai penting yang perlu diterapkan dalam memberikan asuhan keperawatan. Perawat dapat menunjukkan nilai estetika atau aesthetic expression berdasarkan intuisi yang mereka miliki dalam mengatasi masalah kesehatan yang sedang dialami pasien. Penerapan aesthetic expression ini dalam praktik keperawatan dapat berupa tindakan non farmakologis seperti terapi musik, puisi, terapi humor, tarian dan terapi visual art. Namun, literatur terkait aesthetic expression masih terbatas untuk dapat direview. Penelitian selanjutnya diharapkan dapat lebih mengembangkan aethetic expression dan penerapannya pada berbagai populasi khusus pada praktik keperawatan.

\section{REFERENSI}

Awaludin, S., Santoso, A., \& Novitasari, D. (2016). Terapi humor untuk menurunkan intensitas nyeri pada pasien pasca bedah. 1(2), 59-65.

Carper, B. A., \& Learning, B. (1978). Fundamental Patterns of Knowing in Nursing

Chang, C., \& Chen, C. (2012). A "dialogue" between the aesthetic of nursing and 
phylosophy. Journal of Nursing, 59(1), 83-90.

Chinn, P. L. (1997). Aesthetic Inquiry and the Art of Nursing. 11(2), 1997.

Edwards, S. L. (2015). Transforming the findings of narrative research into poetry. Nurse Researcher, 22(5), 35-39.

Hayati, F. (2017). Pengaruh pemberian terapi musik klasik terhadap tingkat kecemasan pada wanita menopause di wilayah pisangan, ciputat timur, tangerang selatan.

Henry, D. (2018). Rediscovering the Art of Nursing for Nursing Practice.

Hunter, B. C., Oliva, R., Sahler, O. J., Gaisser, D., Salipante, D. M., \& Arezina, C. H. (2010). Music therapy as an adjunctive treatment in the management of stress. Journal of Music Therapy, 47(3), 198-219.

Katimis, I. (1993). Nursing as aesthetic experience and the notion of practice. Scholarly Inquiry for Nursing Practice, 7(4), 1-11.

Kim, H. S. (1993). Response to nursing as aesthetic experience and the notion of practice. Scholarly Inquiry for Nursing Practice, 7(4), 1-5.

Luh, N., Dian, P., Sari, Y., \& Rekawati, E. (2018). Literature review: The Benefits of Dance Therapy for Elderly. 6(2).

Prasetyo, A. R., \& Nurtjahjanti, H. (2010). Pengaruh penerapan terapi tawa terhadap penurunan tingkat stres kerja pada pegawai kereta api.

Redmehr, M., Ashktorab, T., \& Abedsaeedi, Z. (2015). Nursing care aesthetic in Iran: A phenomenological study. Nurisng
Midwifery Study, 4(2), 1-8. doi:http://dx.doi.org/10.17795/nmsjourna 127639

Rustam, J., Kongsuwan, W., \& Kitrungrote, L. (2017). Effect of Comfort Care Integrated with the Holy Qur'an Recitation on Comfort of Muslim Patients under Mechanical Ventilation:

A Pilot Study. Medical - Surgical Nursing Journal, 6(1), 34-40. https://doi.org/10.31227/osf.io/y g4xm

Schindler, I., Hosoya, G., Menninghaus, W., Beermann, U., Wagner, V., Eld, M., \& Schere, K. R. (2017). Measuring aesthetic emotions: A review of the literature and a new assessmeent tool. PLOS ONE, 12(6), 1-45. Retrieved from https://doi.org/10.1371/journal.pone.017 8899

Timmermann, C., Uhrendeldt, L., Hoyye, M. T., \& Birkelund, R. (2015). A palliative environment: Caring for seriously ill hospitalized patients. Palliative and Supportive Care, 13, 201-209. doi:10.1017/S147895151300117X

Víctor, C. I. (2013). Evidence of Art in Nursing. Enfermería Global, 332-339.

Wijayanti, K., Johan, A., \& Rochana, N. (2018). Musik Suara Alam Terhadap Peningkatan Kualitas Tidur pada Pasien Kritis. Bhamada: Jurnal IImu Dan Teknologi Kesehatan, 9(1). http://ojs.stikesbhamadaslawi.ac.id/in dex.php/jik/article/view/21

Wikström, B.-M. (2002). Nurse strategies when providing for patients' aesthetic needs. Clinical Nursing Research, 11(1), 22-33. 